Article

\title{
Soil Macroinvertebrate Response to Paddy Rice Farming Pathways in Mpologoma Catchment, Uganda
}

\author{
Jackson Bunyangha ${ }^{1,2, * \mathbb{D}}$, Agnes W. Muthumbi ${ }^{2}$, Nathan N. Gichuki ${ }^{2}$, Mwanjalolo J. G. Majaliwa ${ }^{3}$ \\ and Anthony Egeru 4 (D)
}

1 Department of Science, Technical and Vocational Education, Makerere University, Kampala P.O. Box 7062, Uganda

2 Department of Biology, Faculty of Science and Technology, University of Nairobi, Nairobi P.O. Box 30197, Kenya; amuthumbi@uonbi.ac.ke (A.W.M.); ngichuki@uonbi.ac.ke (N.N.G.)

3 Department of Geography, Geo-Informatics and Climatic Sciences, Makerere University, Kampala P.O. Box 7062, Uganda; majaliwam@gmail.com

4 Department of Environmental Management, Makerere University, Kampala P.O. Box 7062, Uganda; egeru81@gmail.com

* Correspondence: jbjackson2011@gmail.com; Tel.: +256-703-140853

check for updates

Citation: Bunyangha, J.; Muthumbi, A.W.; Gichuki, N.N.; Majaliwa, M.J.G.; Egeru, A. Soil Macroinvertebrate Response to Paddy Rice Farming Pathways in Mpologoma Catchment, Uganda. Agronomy 2022, 12, 312. https://doi.org/10.3390/ agronomy12020312

Academic Editors: Umberto Anastasi Aurelio Scavo and Jiaen Zhang

Received: 23 November 2021

Accepted: 13 January 2022

Published: 26 January 2022

Publisher's Note: MDPI stays neutral with regard to jurisdictional claims in published maps and institutional affiliations.

Copyright: (C) 2022 by the authors. Licensee MDPI, Basel, Switzerland. This article is an open access article distributed under the terms and conditions of the Creative Commons Attribution (CC BY) license (https:// creativecommons.org/licenses/by/ $4.0 /)$.

\begin{abstract}
Agricultural practices play a major role in influencing soil fauna abundance and diversity. Interest in these practices has increased owing to the growing need for sustainable agricultural systems in this era of increasing agricultural intensification. In this study, two paddy rice farming pathways (smallholder and large-scale commercial) and an adjacent natural wetland in Mpologoma catchment were studied to determine the response of soil macroinvertebrates to paddy rice farming pathways. Eighteen macroinvertebrate taxa were observed, some of which were not the usual soil taxa (Hirudinea, Decapoda, Ephemeroptera, Trichoptera, and Odonata). SIMPER analysis showed that Oligochaeta, Gastropoda, and Coleoptera were the major taxa responsible for dissimilarity among sites. Macroinvertebrate richness and diversity also varied among sites. Some taxa showed habitat exclusivity: Diptera, Odonata, and Trichoptera were exclusive to both rice paddies; Decapoda, Chilopoda, Diplopoda, and Blattodea to natural wetland; Diplura and Ephemeroptera were exclusive to large-scale commercial paddies. NMDS ordination showed that macroinvertebrate distribution among sites was strongly correlated with soil $\mathrm{pH}$ and calcium and moderately correlated with phosphorus. These results indicate that wetland conversion to rice paddies could affect macroinvertebrate richness and diversity and underscore the importance of soil environment in influencing the macroinvertebrate community in rice paddies.
\end{abstract}

Keywords: soil fauna; soil quality; agricultural systems; macroinvertebrates; rice paddies; wetlands

\section{Introduction}

Establishing sustainable food production systems is a major global concern, and the need to balance the social, economic, and environmental aspects of crop production has attracted vast research in the area of agricultural sustainability [1,2]. In the rice production sector, however, much of the attention has been focused on yield maximization to meet the high rice demand for nutrition and poverty reduction [3-9]. Research on the environmental impacts of rice production has been limited [10]. In particular, the response of soil invertebrates to paddy rice farming pathways has received negligible focus, yet these invertebrates play a key role in leveraging sustainable paddy rice production [11,12].

Soil invertebrates range in size from the small microfauna (average size $<0.2 \mathrm{~mm}$ ), such as nematodes, through the medium-sized mesofauna $(0.2-2 \mathrm{~mm})$, such as microarthropods and enchytraeids, to the largest macrofauna ( $>2 \mathrm{~mm})$, such as arthropods, molluscs, annelids, and crustaceans $[13,14]$. By decomposing organic matter, modifying soil structure, and mediating nutrient cycling, among other functions, soil invertebrates enhance soil 
quality for sustainable crop production [13-19]. However, conservation of soil invertebrates continues to be a challenge in agricultural landscapes. This is largely attributed to their dwelling in the surface litter or in nests and burrows, such that they create in the top $20 \mathrm{~cm}$ of the soil profile, where they are prone to physical, chemical, or biological disturbance $[13,20,21]$. The sensitivity to disturbance is of utmost ecological significance in the function of soil invertebrates as bioindicators [22-25], and changes in their community characteristics can provide valuable feedback on prevailing soil management practices.

Many authors have highlighted the effects of conventional farm management practices on soil invertebrates [26-29]. They have shown how agricultural practices, such as tillage and field traffic (machine compaction), can affect soil invertebrate populations and reduce crop yields [30-32]. Irrigation has also been reported to reduce soil arthropod abundance: Menta et al. [20] observed that Acari, Collembola, and Hymenopteran numbers were higher in corn and wheat fields which had conservation (non-irrigated) soil management practices than in fields with conventional (irrigated) soil management practices. John et al. [33] also observed that microarthropod (mite and collembola) preferred a non-flooded crop rotation environment, unlike the enchytraeids. Similarly, agrochemical use is also reported to interfere with the soil invertebrate environment. For instance, Förster et al. [34] observed that the use of fungicide carbendazim and insecticide lambda-cyhalothrin reduces millipede Trigoniulus corallinus and earthworm Pontoscolex corethrurus abundance in terrestrial systems. However, it should be noted that, although the majority of the studies have reported detrimental effects, not all conventional farm management practices cause negative effects on soil biodiversity. For example, nitrogen $(\mathrm{N})$ fertilizer addition has been demonstrated to increase mesostigmata mite richness and collembolan abundance, whereas reduced soil disturbance increased the species richness, abundance, and diversity of oribatid mites and collembola [35].

Most studies on the effect of management practice on soil biodiversity in croplands have been carried out in terrestrial areas. Studies targeting wetland environments and rice paddies in particular are few and have mainly focused on the effect of crop rotation [33,36]. No study has dealt with the response of soil macroinvertebrates to paddy rice farming pathways. A farming pathway is defined, in this study, as the course of agricultural management practices followed on a particular farm during a cropping cycle. Accordingly, two categories of paddy rice farming pathways are recognized in the paddy rice farming system: subsistence smallholder pathway and large-scale commercial farming pathway. These pathways differ in many respects including extent of mechanization, sown crop varieties, irrigation, technical agronomic services (fertilizer, pesticide, extension services), and farm size $[2,37,38]$. Subsistence smallholder farmers cultivate a threshold of 2 ha of land mainly for home consumption and are generally more resource constrained than their large-scale commercial counterparts [38-40]. We assumed that the management practices along each of these paddy rice farming pathways could have unique implications on the community characteristics of the soil macroinvertebrates.

Therefore, in this study, we investigated the response of soil macroinvertebrate taxa in terms of occurrence frequency, richness, abundance, evenness, and diversity in the different paddy rice farming pathways. Macroinvertebrate densities were further correlated with soil characteristics, such as $\mathrm{pH}$, organic matter, nitrogen, phosphorus, potassium, and texture. We hypothesized that the frequency, abundance, richness, evenness, and diversity of macroinvertebrates would reduce along land use intensification gradient from natural wetland, through smallholder paddies, to large-scale commercial paddies. Furthermore, since paddies have unique soil and hydrological conditions, their macroinvertebrate community would be expected to at least encompass some terrestrial or aquatic taxa, such as the arthropod larvae and pupae. 


\section{Materials and Methods}

\subsection{Study Sites}

This study was carried out in Mpologoma catchment, a renowned paddy rice growing watershed, in eastern Uganda (Figure 1). The catchment derives its name from River Mpologoma, which forms the major drainage network in the region. In the Mpologoma River's drainage system are several wetlands that the local communities have largely converted for rice growing. Majority of the rice paddies are of the smallholder type but there is also one large-scale commercial farm known as the Kibimba Rice Scheme. The Kibimba Rice Scheme is located at latitude $0^{\circ} 32^{\prime} 2462 \mathrm{~N}$ and longitude $33^{\circ} 52^{\prime} 9350 \mathrm{E}$ and covers an area of 4350 hectares. It was established in 1973 by the government of Uganda to increase food production $[37,41]$. However, it is currently a private venture. The farmed area covering 3900 ha is divided into 18 blocks and each block is further subdivided into 4-6 strips of 1-4 plots. This area receives an annual rainfall of between 900-1400 $\mathrm{mm}$ and has 2 rainy seasons, late February-May and August-November, with a peak in April [41].

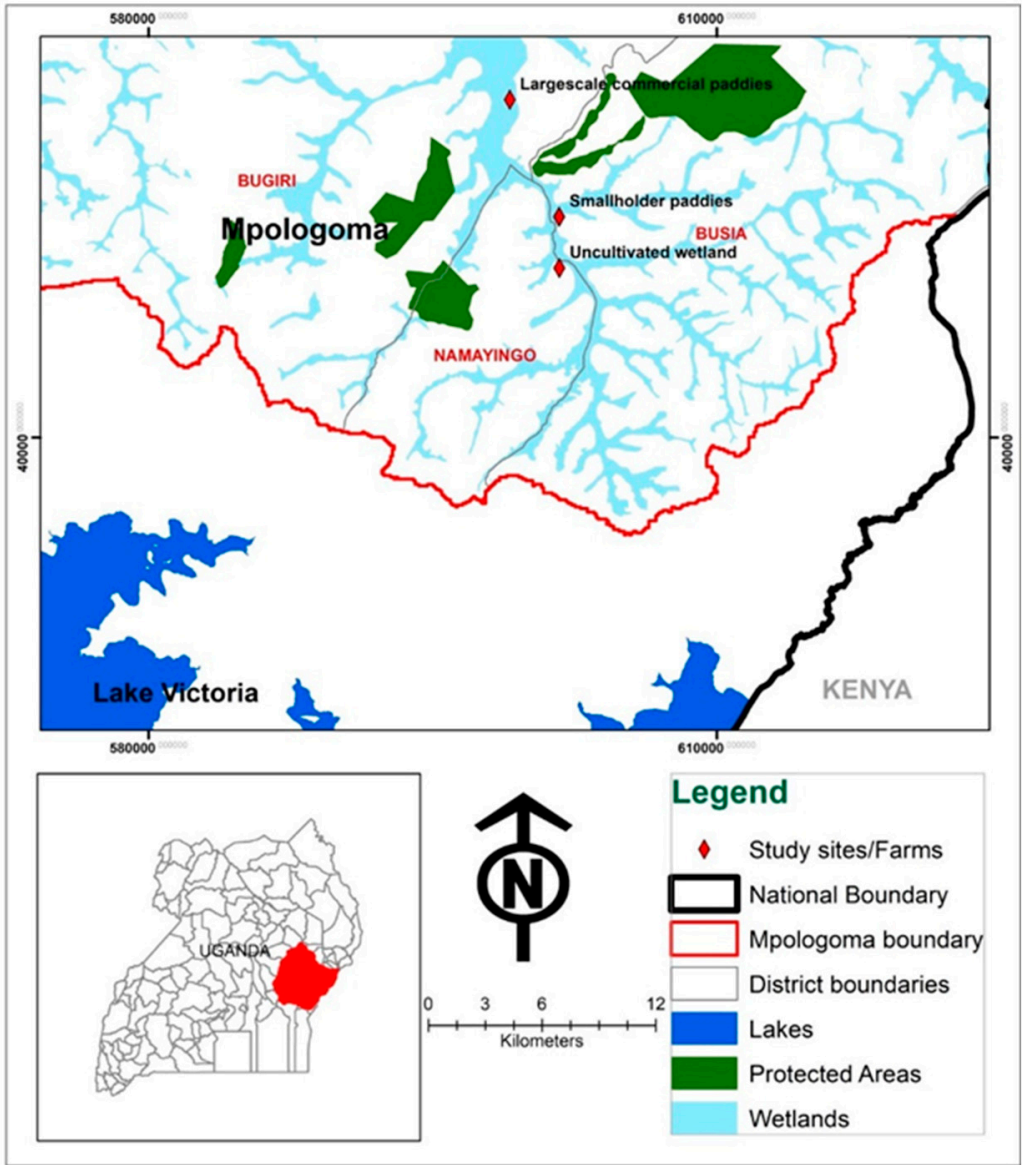

Figure 1. Location of the study sites in Mpologoma catchment.

Rice farming at the large-scale commercial farm (COM) is highly mechanized from land preparation to harvesting. The soil is clayish (Table S3). Ploughing of the land and seeding are mainly carried out twice a year in September-October and March-April. Rice growing is possible throughout the year due to the readily available irrigation water supplied from the reservoir (dam) constructed across River Kibimba. Flooding and drainage of rice fields is regulated through sluice gates constructed across the water canals. Herbicides, fertilizers, and pesticides are regularly used on the farm during the production cycle. The most commonly used herbicides include Glyphosate, which is mainly applied to control volunteer plants that emerge after primary cultivation, and D-Amine for post-emergence weeds in the first weeks of transplanting. The 1st fertilizer application to seedlings is carried 
out 11 days after sowing seeds in the nursery, while transplanting occurs at 25-28 days. Further fertilizer applications are carried out 5-7 days after transplanting the seedlings, then 30 days later, and the last dose is applied at 60 days after transplanting. The fields are flooded with water from the 65th day and this can go on till the 100th day. Afterwards, the plots are drained in preparation for harvesting about 20 days later. Rice varieties at the commercial farm are the short-duration type (mainly K 23, K 85, and Pusa) that mature between 105 and 120 days. Dimethoate and Beam can be applied when required to control stem borers and leaf fungi, respectively. Harvesting mainly occurs during the June-July and December-January dry seasons and it is carried out by combine harvesters. Fallowing is rare but if any, it may be between 1 and 2 growing seasons.

The smallholder rice paddies (SHD), on the other hand, are rain-fed and largely tilled using hand hoes or ox-ploughs. The soil texture is clay loam (Table S3). The plots are small, some measuring about $50 \mathrm{ft}$ by $100 \mathrm{ft}$, and a farmer may use one or more plots for rice farming. Slash-and-burn is commonly practiced for field preparation. Planting usually occurs during the rainy seasons of late February-early March and late August-early September and the crop is harvested during the June-July and December-January dry seasons after about $3^{1} / 2^{-4}$ months. Land preparation, planting, weeding, and rice harvesting rely on family or hired human labor. Agrochemicals, such as fertilizers, herbicides, and pesticides are not used on these farms. After harvest, some farmers immediately hand-till their fields in preparation for the next season, although others may choose to fallow their rice fields for a season or two.

A third sampling site, an uncultivated natural wetland (Uncul), was adopted as a control. The Uncul soil texture is loam (Table S3). The natural wetland is fed by river water flowing into the reservoir that supplies the large-scale commercial farm. It had pristine wetland vegetation cover and was hardly influenced by human activities, like that in the rice paddies. The vegetation mainly comprised Cyperus papyrus L., Cyperus latifolius Poir., Cycads, Impatiens tinctoria A.Rich, Phragmites australis (Cav.) Trin and Echinocloa pyramidalis (Lam.) Hitch., and Chase.

All the three sites (COM, SHD, and Uncul) were similar by being wetland areas located close to each other within a $10 \mathrm{~km}$ radius and had been under the particular land use/cover type and climatic conditions for at least 30 years [42].

\subsection{Soil Sampling and Macroinvertebrate Extraction}

Soil sampling for macroinvertebrate and chemical characteristics was carried out between September 2018 and December 2019. For macroinvertebrate analysis, four replicate plots were randomly selected in the large-scale and small-scale rice paddies for each crop stage: young rice (about one month after transplanting), mature rice (at harvest), and fallow (unplowed rice fields after harvest for at least one season). This was aimed at capturing the variability in macroinvertebrate community within and between farming pathways. In each plot, 3 monoliths measuring $25 \times 25 \times 15 \mathrm{~cm}$ deep were randomly dug out along a diagonal transect. The exact position of the monoliths was marked out using a wooden quadrat of $25 \times 25 \mathrm{~cm}$ outside dimensions. In the first 2 days of invertebrate collection in September 2018, monoliths were initially dug to a depth of $30 \mathrm{~cm}[43,44]$. However, because deep layers $(15-30 \mathrm{~cm})$ had barely any macroinvertebrates, sampling depth was adjusted to $0-15 \mathrm{~cm}$ in the later sampling. Similarly, soil replicates were collected from four randomly selected plots located in the natural wetland. However, since there were not crop stages in the natural wetland, 12 soil samples were collected from the 4 plots. Therefore, in total, 84 soil samples were collected. At each sampling point, litter within the $25 \mathrm{~cm}$ quadrat was initially hand-sorted for any surface macroinvertebrates before the monolith was dug out. Then, the monolith was carried to the sorting area, crumbled and all large invertebrates ( $>5 \mathrm{~mm}$ long) and visible under a magnifying glass were carefully hand-sorted and removed with forceps. The soil sample was subsequently mixed with water in a bucket and sieved over a $2 \mathrm{~mm}$ sieve to maximize extraction of macroinvertebrates. The collected macroinvertebrates were preserved in $10 \%$ formalin and 
carried to the laboratory where they were stained with Rose Bengal to ease sorting and counting under a binocular dissecting microscope.

Soil samples for chemical analysis were also collected from the top $0-15 \mathrm{~cm}$ adjacent to the sampling locations for soil samples for fauna analysis. The samples were then mixed homogeneously, air-dried, their gravel, roots, and large organic residues were removed, and then they were passed through a $2 \mathrm{~mm}$ sieve. Generally, analysis of soil samples for chemical parameters was performed following procedures described in [45]. The parameters measured included $\mathrm{pH}$, texture (\%), soil organic matter $(\%)$, available phosphorus (ppm), available nitrogen (\%), available potassium ( $\mathrm{cmol} / \mathrm{Kg}$ of soil), available sodium $(\mathrm{cmol} / \mathrm{Kg}$ of soil), and available calcium $(\mathrm{cmol} / \mathrm{Kg}$ of soil). Soil texture was classified following the USDA soil texture triangle classification [46].

\subsection{Data Analysis}

Macroinvertebrate data were collected in terms of abundance of invertebrate taxa per soil sample. Frequency of occurrence of each taxon was then derived by considering the number of soil samples in which a particular taxon was present against the total number of replicates over the entire study. Community indices, such as richness, evenness, and diversity were also obtained. Diversity and evenness of soil macroinvertebrates were, respectively, calculated using Equations (1) and (2) [47-50], as follows:

$$
\begin{gathered}
H^{\prime}=-\sum_{i=1}^{s} p_{i} * \operatorname{In}\left(p_{i}\right) \\
J=H^{\prime} / \operatorname{In}(s)
\end{gathered}
$$

where $H^{\prime}$ is the Shannon-Wiener diversity index, $s$ is the total number of taxa collected, $p_{i}$ is the proportion of individuals of taxon $i\left(n_{i}\right)$ relative to all individuals $(N)$ from all the collected taxa for a particular land use $\left(p_{i}=n_{i} / N\right)$, and $J$ is Pielou's measure of evenness.

Rank-abundance curves were then produced to display the relative abundance of macroinvertebrate taxa for each farming pathway and natural wetland. Macroinvertebrate abundances, richness, evenness, and diversity were further compared across sites and crop stages using one-way ANOVA in R 4.0.4 [51]. This aimed to establish whether or not the differences in means varied among the categories. Count data were standardized to densities (ind. $/ \mathrm{m}^{2}$ ) [43], normality, and homoscedasticity evaluated using the Shapiro-Wilk test and Levene's test, respectively.

To visualize how farming pathway related with the macroinvertebrate community, non-metric multidimensional scaling (NMDS) was performed based on Bray-Curtis dissimilarity index $[52,53]$. The results were plotted in an NMDS ordination plane, in a two-dimensional space. Differences in the macroinvertebrate community among the different patterns visualized with NMDS were analyzed using a permutational multivariate analysis of variance (PERMANOVA) test. After a significant PERMANOVA test $(p \leq 0.05)$, SIMPER (similarity percentages) analysis was performed to examine which invertebrate groups were driving the differences in community among the sites. The significance of contribution of each macroinvertebrate group to the differences and which of the soil environmental factors ( $\mathrm{pH}, \mathrm{SOM}, \mathrm{N}, \mathrm{P}, \mathrm{K}, \mathrm{Na}, \mathrm{Ca}$, and texture) were significantly correlated to the first two axes of the NMDS ordination plane were tested using the envfit function. NMDS ordination, PERMANOVA, SIMPER, and envfit function were performed with the vegan package (2.5-7) in R 4.0.4 [51,54].

\section{Results}

\subsection{Macroinvertebrate Community Composition}

A total of 18 macroinvertebrate taxa were observed in the soil samples. They belonged to 3 phyla Annelida, Mollusca, and Arthropoda at $61.3 \%, 17.9 \%$, and $20.8 \%$, respectively (Table S1). The arthropods were mainly larvae and nymphs. Oligochaeta (57.3\%), Gastropoda $(17.9 \%)$, Coleoptera (12.4\%), Hirudinea $(4.0 \%)$, Hymenoptera (2.1\%), Diptera (1.6\%), 
and Trichoptera (1.1\%) were the most abundant groups and constituted about $96 \%$ of the macroinvertebrates. Arachnida, Isopoda, Dermaptera, and Orthoptera comprised about 3\% while the rest of the taxa Decapoda, Diplopoda, Chilopoda, Diplura, Ephemeroptera, Blattodea, and Odonata totaled less than $1 \%$. In addition, Oligochaeta was the most ubiquitous taxon followed by Coleoptera, Gastropoda, and Hirudinea (Table S2). Macroinvertebrate occurrence frequencies across sites and crop stages did not follow a specific pattern. For instance, oligochaetes occurred in $100 \%, 97 \%$, and $72 \%$ of the soil samples collected from the natural wetland, smallholder paddies, and large-scale commercial paddies, respectively; meanwhile, Coleoptera were mainly found in soil samples from the large-scale commercial paddies $(66.7 \%)$, followed by natural wetland (58.3\%), and least in the smallholder paddies (33.3\%). Similarly, the majority of the Gastropods and Hirudinea were encountered in the large-scale commercial paddies (72.2\% and 50.0\%, respectively), followed by smallholder paddies (33.3\% and $38.9 \%$, respectively), and natural wetland $(25.0 \%$ and $8.3 \%$, respectively). Overall, eight of the taxa were common to all the three sites. One taxon (Isopoda) was common to both large-scale commercial paddies and natural wetland, while three taxa (Diptera, Odonata, and Trichoptera) were common to both large-scale commercial and smallholder paddies. Four taxa (Decapoda, Chilopoda, Diplopoda, and Blattodea) were exclusive to the natural wetland, while two taxa (Diplura and Ephemeroptera) were exclusive to the large-scale commercial paddies. No taxa were exclusive to smallholder paddies and none to both smallholder and natural wetland. Taxa such as Hirudinea, Decapoda, Trichoptera, Ephemeroptera, and Odonata which are not regular soil candidates, especially in terrestrial soils, were also encountered in the samples.

The overall macroinvertebrate density was $304.8 \pm 327.6 \mathrm{ind} . / \mathrm{m}^{2}$ and ranged between $284.0 \pm 210.3 \mathrm{ind} . / \mathrm{m}^{2}$ (in the natural wetland), $307.6 \pm 357.2 \mathrm{ind} . / \mathrm{m}^{2}$ (in the large-scale commercial paddies), and $308.9 \pm 336.0$ ind.$/ \mathrm{m}^{2}$ (in the smallholder farms) (Table 1). Density per replicate ranged between 16 and $1584 \mathrm{ind} . / \mathrm{m}^{2}$ in the large-scale rice paddies, 32 and 1872 ind. $/ \mathrm{m}^{2}$ in the smallholder paddies, and 32 and $736 \mathrm{ind} . / \mathrm{m}^{2}$ in the natural wetland. Across the crop stages, macroinvertebrate density was highest in the smallholder harvest $\left(353.3 \pm 493\right.$ ind. $\left./ \mathrm{m}^{2}\right)$ and lowest in the commercial fallow $\left(250.7 \pm 247.5 \mathrm{ind} . / \mathrm{m}^{2}\right)$. There was high variability in density among replicates and it muffled any significant differences in total density between crop stages and sites. Nevertheless, some taxa showed significant differences in their density among sites. For instance, Oligochaeta, the most abundant taxon overall, had highest density $\left(253.8 \pm 345.2 \mathrm{ind} . / \mathrm{m}^{2}\right)$ in the smallholder paddies compared with the large-scale paddies $\left(86.2 \pm 193.7 \mathrm{ind} . / \mathrm{m}^{2}\right)$ and the natural wetland $\left(202.7 \pm 200.7 \mathrm{ind} . / \mathrm{m}^{2}\right)$ and this variation among sites was significant $(p<0.05)$. Post hoc comparison indicated that the difference was mainly between the smallholder and large-scale pair $(p<0.05)$.

The second most abundant taxon was Gastropoda. It recorded significantly higher densities $(p<0.05)$ in the large-scale paddies $\left(111.1 \pm 212.7 \mathrm{ind} . / \mathrm{m}^{2}\right)$ compared with smallholder rice paddies $\left(12.4 \pm 31.6 \mathrm{ind} . / \mathrm{m}^{2}\right)$ and natural wetland $\left(10.7 \pm 21.9 \mathrm{ind} . / \mathrm{m}^{2}\right)$. A post hoc test showed that the difference was also mainly between the smallholder and large-scale paddies $(p<0.05)$. The other important taxon in terms of density was Coleoptera. Coleoptera had a relatively higher density in the large-scale commercial paddies $\left(72.0 \pm 214.4 \mathrm{ind} . / \mathrm{m}^{2}\right)$ compared with smallholder rice paddies $\left(9.8 \pm 24.9 \mathrm{ind} . / \mathrm{m}^{2}\right)$ and natural wetland $\left(18.7 \pm 19.1 \mathrm{ind} . / \mathrm{m}^{2}\right)$, but the difference among sites was not significant $(p>0.05)$. The rest of the taxa recorded relatively low densities and the differences were also not significant among sites and crop stages $(p>0.05)$. 
Table 1. Mean density \pm SD (ind. $\mathrm{m}^{-2}$ ) of soil macroinvertebrate taxa by site and crop stage.

\begin{tabular}{|c|c|c|c|c|c|c|c|c|c|c|}
\hline \multirow[b]{2}{*}{ Taxa } & \multicolumn{6}{|c|}{ Crop Stages } & \multicolumn{3}{|c|}{ Sites } & \multirow[b]{2}{*}{ Overall } \\
\hline & Com-You & Com-Har & Com-Fal & Shd-You & Shd-Har & Shd-Fal & Com & Shd & $\begin{array}{l}\text { Natural } \\
\text { Wetland }\end{array}$ & \\
\hline Oligochaeta & $176 \pm 313.8$ & $58.7 \pm 77.3$ & $24.0 \pm 33.1$ & $186.7 \pm 260.4$ & $313.3 \pm 503.4$ & $261.3 \pm 221.8$ & $86.2 \pm 193.7$ & $253.8 \pm 345.2$ & $202.7 \pm 200.7$ & $174.7 \pm 278.7$ \\
\hline Hirudinea & $10.7 \pm 19.7$ & $13.3 \pm 19.1$ & $18.7 \pm 16.5$ & $14.7 \pm 27.7$ & $4.0 \pm 9.9$ & $22.7 \pm 22.1$ & $14.2 \pm 18.3$ & $13.8 \pm 22.0$ & $1.3 \pm 4.6$ & $12.2 \pm 19.2$ \\
\hline Gastropoda & $140 \pm 300$ & $49.3 \pm 74.9$ & $144.0 \pm 205.1$ & $22.7 \pm 48.9$ & $13.3 \pm 22.5$ & $1.3 \pm 4.6$ & $111.1 \pm 212.7$ & $12.4 \pm 31.6$ & $10.7 \pm 21.9$ & $54.5 \pm 148.3$ \\
\hline Arachnida & - & $2.7 \pm 9.2$ & $6.7 \pm 12.7$ & $2.7 \pm 6.2$ & $1.3 \pm 4.6$ & - & $3.1 \pm 9.2$ & $1.3 \pm 4.5$ & $5.3 \pm 14.2$ & $2.7 \pm 8.5$ \\
\hline Isopoda & - & $2.7 \pm 9.2$ & - & - & - & - & $0.9 \pm 5.3$ & - & $9.3 \pm 27.7$ & $1.7 \pm 11.1$ \\
\hline Decapoda & - & - & - & - & - & - & - & - & $1.3 \pm 4.6$ & $0.2 \pm 1.7$ \\
\hline Coleoptera & $6.7 \pm 8.2$ & $164 \pm 356$ & $45.3 \pm 69.2$ & $9.3 \pm 12.7$ & $2.7 \pm 6.2$ & $17.3 \pm 40.6$ & $72.0 \pm 214.4$ & $9.8 \pm 24.9$ & $18.7 \pm 19.1$ & $37.7 \pm 143.5$ \\
\hline Diptera & $5.3 \pm 14.2$ & $9.3 \pm 18.6$ & $1.3 \pm 4.6$ & $13.3 \pm 22.5$ & $4.0 \pm 7.2$ & $1.3 \pm 4.6$ & $5.3 \pm 13.8$ & $6.2 \pm 14.5$ & - & $5.0 \pm 13.1$ \\
\hline Dermaptera & - & $6.7 \pm 10.7$ & - & - & $1.3 \pm 4.6$ & - & $2.2 \pm 6.8$ & $0.4 \pm 2.7$ & $5.3 \pm 7.9$ & $1.9 \pm 5.5$ \\
\hline Diplura & $1.3 \pm 4.6$ & $1.3 \pm 4.6$ & - & - & - & - & $0.9 \pm 3.7$ & - & - & $0.4 \pm 2.5$ \\
\hline Chilopoda & - & - & - & - & - & - & - & - & $2.7 \pm 9.2$ & $0.4 \pm 3.5$ \\
\hline Diplopoda & - & - & - & - & - & - & - & - & $1.3 \pm 4.6$ & $0.2 \pm 1.7$ \\
\hline Ephemeroptera & - & - & $1.3 \pm 4.6$ & - & - & - & $0.4 \pm 2.7$ & - & - & $0.2 \pm 1.7$ \\
\hline Orthoptera & $1.3 \pm 4.6$ & - & $5.3 \pm 14.2$ & $1.3 \pm 4.6$ & - & $4.0 \pm 9.9$ & $2.2 \pm 8.7$ & $1.8 \pm 6.4$ & $6.7 \pm 12.7$ & $2.7 \pm 8.5$ \\
\hline Blattodea & - & - & - & - & - & - & - & - & $1.3 \pm 4.6$ & $0.2 \pm 1.7$ \\
\hline Trichoptera & - & $18.7 \pm 35.3$ & $2.7 \pm 6.2$ & $1.3 \pm 4.6$ & - & - & $7.1 \pm 21.8$ & $0.4 \pm 2.7$ & - & $3.2 \pm 14.6$ \\
\hline Overall & $342.7 \pm 401.7$ & $329.3 \pm 404$ & $250.7 \pm 275.5$ & $260.0 \pm 247.5$ & $353.3 \pm 493$ & $313.3 \pm 223.7$ & $307.6 \pm 357.2$ & $308.9 \pm 336.0$ & $284.0 \pm 210.3$ & $304.8 \pm 327.6$ \\
\hline
\end{tabular}




\subsubsection{Richness, Evenness, and Diversity}

Macroinvertebrate richness ranged between $3.47 \pm 1.38$ in the large-scale paddies, $3.42 \pm 2.07$ in the natural wetland, and $2.64 \pm 1.22$ in the smallholder paddy soil replicates (Table 2). The difference in richness among sites was significant $(p<0.05)$ and a post hoc test indicated that it was significant between the smallholder and large-scale paddies pair $(p<0.05)$. Similarly, the diversity of macroinvertebrates was $0.85 \pm 0.48,0.72 \pm 0.65$, and $0.56 \pm 0.44$ in the large-scale commercial paddies, natural wetland, and smallholder paddies, respectively. It significantly varied among sites $(p<0.05)$ and was also between the smallholder and large-scale commercial paddies pair $(p<0.05)$. On the other hand, variation in evenness among sites was not significant $(p>0.05)$.

Table 2. Mean \pm SD richness, evenness and diversity of macroinvertebrates across crop stages and sites.

\begin{tabular}{|c|c|c|c|c|c|c|c|c|c|}
\hline \multirow{2}{*}{ Index } & \multicolumn{6}{|c|}{ Crop Stages } & \multicolumn{3}{|c|}{ Sites } \\
\hline & Com-You & Com-Har & Com-Fal & Shd-You & Shd-Har & Shd-Fal & Com & Shd & Uncul \\
\hline $\begin{array}{l}\text { Richness per } \\
\text { replicate }\end{array}$ & $2.83 \pm 1.27$ & $4.08 \pm 0.90$ & $3.50 \pm 1.68$ & $3.17 \pm 1.47$ & $2.25 \pm 1.29$ & $2.50 \pm 0.67$ & $3.47 \pm 1.38$ & $2.64 \pm 1.22$ & $3.42 \pm 2.07$ \\
\hline $\begin{array}{c}\text { Pileou's } \\
\text { Evenness }\left(J^{\prime}\right)\end{array}$ & $0.53 \pm 0.36$ & $0.80 \pm 0.16$ & $0.65 \pm 0.35$ & $0.61 \pm 0.30$ & $0.35 \pm 0.37$ & $0.54 \pm 0.31$ & $0.66 \pm 0.31$ & $0.50 \pm 0.34$ & $0.53 \pm 0.35$ \\
\hline $\begin{array}{c}\text { Shannon's } \\
\text { Diversity }\left(\mathrm{H}^{\prime}\right)\end{array}$ & $0.59 \pm 0.46$ & $1.10 \pm 0.32$ & $0.87 \pm 0.53$ & $0.77 \pm 0.46$ & $0.39 \pm 0.48$ & $0.52 \pm 0.31$ & $0.85 \pm 0.48$ & $0.56 \pm 0.44$ & $0.72 \pm 0.65$ \\
\hline
\end{tabular}

Abbreviations: Com—large-scale commercial paddies; Shd—smallholder paddies; You—young; Har—harvest/mature; Fal-fallow.

\subsubsection{Rank Abundance Relationship}

The macroinvertebrate community of the sampled sites was characterized by a few abundant taxa (Figure 2). The steepest slope was for smallholder rice paddies with one dominant taxon, followed by natural wetland with a less steep slope than for smallholder paddies, and also dominated by one taxon, and then the largescale commercial paddies with a shallower gradient but with three relatively more evenly abundant taxa. The majority of the taxa fell in the rare category, arbitrarily defined in this study as a relative abundance of $0.5 \%$ or less in a given farming pathway or natural wetland over the entire study.

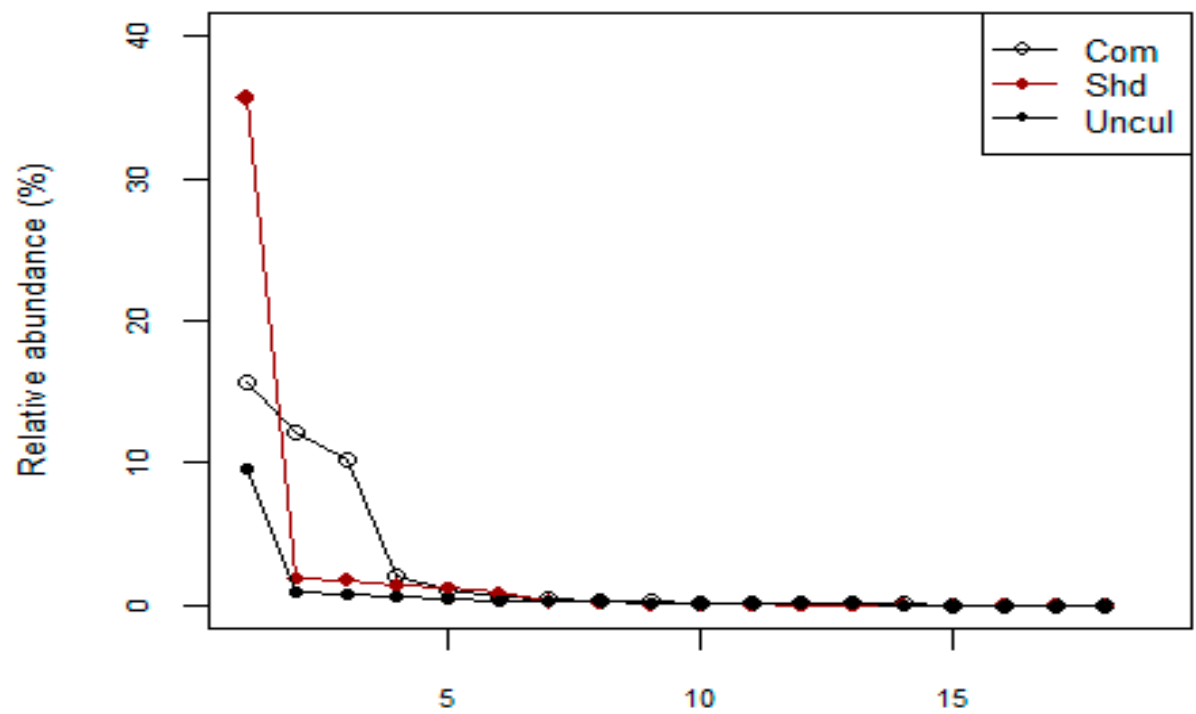

Abundance Rank

Figure 2. Rank abundance curves for the soil macroinvertebrates observed in the paddy rice farming pathways in Mpologoma catchment. Abbreviations: Com-large-scale commercial paddies; Shd—smallholder paddies; Uncul—natural wetland. 


\subsubsection{Community Ordination}

The macroinvertebrate community in the large-scale commercial rice paddies (COM), smallholder rice paddies (SHD), and natural wetland (Uncul) showed some overlap (Figure 3), especially between SHD and Uncul, and 15\% of the variation in communities was due to management differences as confirmed by PERMANOVA $\left(p \leq 0.001, R^{2}=0.151\right)$. A subsequent pairwise SIMPER analysis to examine the average contribution of the different macroinvertebrate groups to the overall dissimilarity between site pairs revealed that Oligochaeta, Gastropoda, and Coleoptera were the most influential taxa (Table 3). Oligochaetes contributed largest to the variation in each site pair. In addition, the first 2 invertebrate taxa accounted for over $60 \%$ of the dissimilarity in each pairwise site comparison, while with the third taxon, Coleoptera, over $75 \%$ of the dissimilarity between sites could be explained. Further analysis of the intrinsic taxa indicated that Oligochaeta, Gastropoda, Coleoptera, and Odonata were the only taxa that had significant contribution to the overall dissimilarity among sites (Table 4).

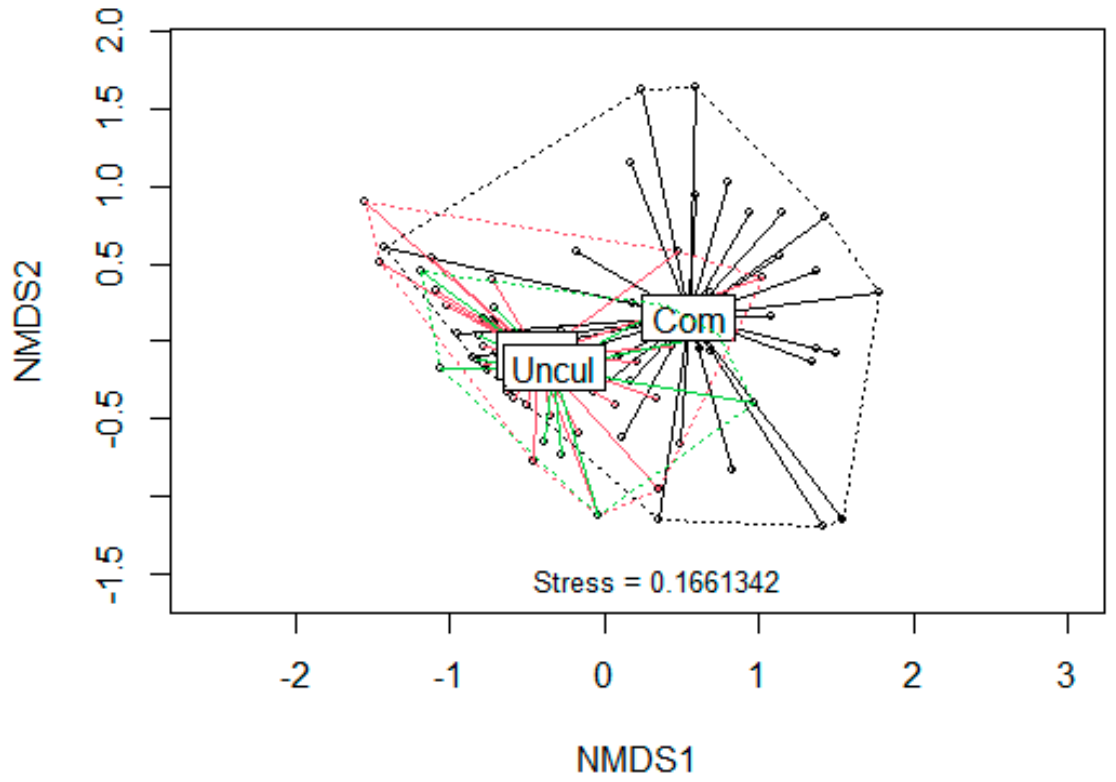

Figure 3. Bray-Curtis based NMDS plot of soil macroinvertebrate community composition. Points represent macroinvertebrate samples condensed on the two axes of NMDS plot. Spider diagrams connect the points to the respective land use type: Com (black), Uncul (green), and Shd (red).

Table 3. Cumulative percentage contribution of most influential taxa to the overall similarity between site pairs.

\begin{tabular}{cccc}
\hline $\begin{array}{c}\text { Macroinvertebrate } \\
\text { Community Pair }\end{array}$ & Oligochaeta & $\begin{array}{c}\text { Oligochaeta and } \\
\text { Gastropoda }\end{array}$ & $\begin{array}{c}\text { Oligochaeta, Gastropoda, } \\
\text { and Coleoptera }\end{array}$ \\
\hline Com-Shd & 47 & 69 & 82 \\
Com-Uncul & 43 & 65 & 78 \\
Shd-Uncul & 59 & 67 & 74 \\
\hline Abbreviations: Com-large-scale commercial paddies; Shd—-smallholder paddies; Uncul-natural wetland.
\end{tabular}

Table 4. Taxa driving the overall distribution pattern across sites.

\begin{tabular}{ccc}
\hline Taxa & Squared Correlation Coefficient, $\mathbf{R}^{2}$ & $p$-Value \\
\hline Oligochaeta & 0.5245 & $0.001^{* * *}$ \\
Gastropoda & 0.3677 & $0.001^{* * *}$ \\
Coleoptera & 0.1871 & $0.001^{* * *}$ \\
Odonata & 0.1477 & $0.002^{* *}$ \\
\hline
\end{tabular}

Significance codes: ${ }^{* *} p<0.01,{ }^{* * *} p<0.001$. 


\subsection{Soil Environment and Its Relationship with Macroinverterbate Community}

Generally, soil characteristics varied across the sites (Table S3). The overall average $\mathrm{pH}$ was $5.73 \pm 0.06$ and ranged between $5.54 \pm 0.11$ in the large-scale commercial paddies, $5.81 \pm 0.08$ in smallholder paddies, and $6.03 \pm 0.11$ in natural wetland. The difference in $\mathrm{pH}$ among sites was significant $(p<0.05)$ and the post hoc test showed that it was mainly from the natural wetland and large-scale paddies pair $(p<0.05)$. Similarly, soil organic matter (SOM), nitrogen $(\mathrm{N})$, phosphorus $(p)$, and calcium $(\mathrm{Ca})$ contents were, respectively, $37.53 \pm 3.74 \%, 0.46 \pm 0.06 \%, 0.24 \pm 0.02 \mathrm{ppm}$, and $51.64 \pm 11.48 \mathrm{cmol} / \mathrm{Kg}$ in the natural wetland, $26.36 \pm 2.5 \%, 0.46 \pm 0.02 \%, 0.18 \pm 0.01 \mathrm{ppm}$, and $30.63 \pm 5.21 \mathrm{cmol} / \mathrm{Kg}$ in the smallholder paddies, and $17.7 \pm 1.38 \%, 0.43 \pm 0.02 \%, 0.13 \pm 0.01 \mathrm{ppm}$, and $8.17 \pm 1.44 \mathrm{cmol} / \mathrm{Kg}$ in the large-scale commercial rice paddies. There were significant differences $(p<0.001)$ in the variation of phosphorus and calcium among sites. Post hoc test indicated that the differences in $p$ and Ca were between the pairs: natural wetland and large-scale paddies $(p<0.001$ and $p<0.001$, respectively), smallholder and large-scale paddies $(p<0.01$ and $p<0.01$, respectively), and natural wetland and smallholder paddies $(p<0.01$ and $p<0.1$, respectively). Similarly, the percentage of clay varied $(p<0.001)$ such that it was highest in the large-scale paddies $(41.39 \pm 1.57 \%)$, followed by smallholder paddies $(32.56 \pm 1.73 \%)$, and lowest in the natural wetland $(24.50 \pm 3.42 \%)$. On the other hand, sand also varied $(p<0.01)$ being highest in the natural wetland $(44.25 \pm 1.56 \%)$, followed by smallholder paddies $(40.64 \pm 2.31 \%)$, and large-scale paddies $(33.89 \pm 1.56 \%)$. Post hoc test showed that the differences in sand and clay composition were between the pairs: smallholder and large-scale commercial paddies ( $p<0.05$ and $p<0.01$, respectively) and natural wetland and large-scale commercial paddies ( $p<0.05$ and $p<0.001$, respectively). No significant differences were observed for SOM, sodium $(\mathrm{Na})$, nitrogen $(\mathrm{N})$, potassium $(\mathrm{K})$, and silt.

Soil environment variables were further correlated with the NMDS ordination scores of the macroinvertebrate community. Soil $\mathrm{pH}, \mathrm{Ca}, \mathrm{P}$, and sand had a negative correlation while clay content had a positive correlation (Figure 4). Basing on $\mathrm{R}^{2}$ and the $p$-values to discriminate the strength of the relationship, it was shown that there was a strong correlation for $\mathrm{pH}$ and calcium $(p<0.001)$, moderate intensity correlation for phosphorus $(p<0.01)$, and a low intensity correlation for clay and sand $(p<0.05)$ (Table 5). SOM, N, $\mathrm{Na}, \mathrm{K}$, and silt were not significantly correlated with the NMDS ordination pattern of the macroinvertebrates in this study.

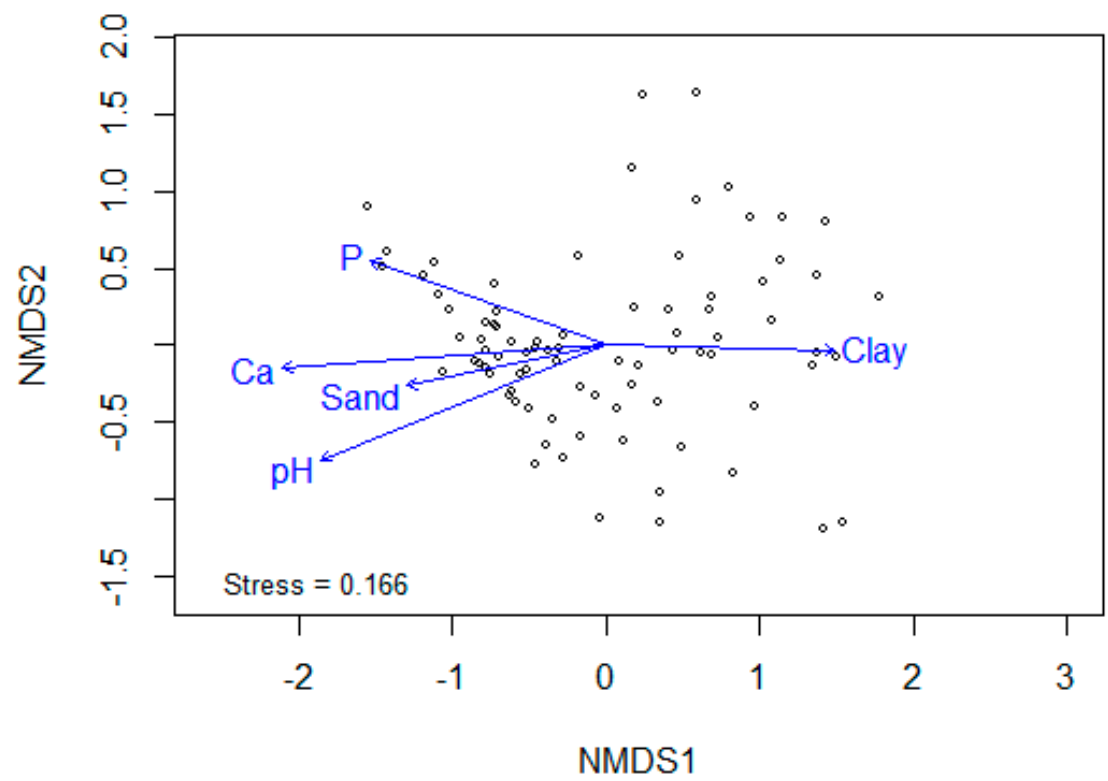

Figure 4. Soil environment variables correlated with macroinvertebrate samples in an ordination system. Points represent samples. Arrows show the significant vectors while their direction represents the gradient direction of the environmental driver. 
Table 5. Correlation analysis of soil characteristics with NMDS scores.

\begin{tabular}{ccc}
\hline Variable & R-Squared & $p$-Value \\
\hline $\mathrm{pH}$ & 0.1954 & $0.001^{* * *}$ \\
\hline $\mathrm{SOM}^{1}$ & 0.0231 & 0.394 \\
\hline $\mathrm{N}$ & 0.0291 & 0.305 \\
\hline $\mathrm{P}$ & 0.1256 & $0.007^{* *}$ \\
\hline $\mathrm{K}$ & 0.0398 & 0.193 \\
\hline $\mathrm{Na}$ & 0.0397 & 0.181 \\
\hline $\mathrm{Ca}$ & 0.2156 & $0.001^{* * *}$ \\
\hline Sand & 0.0855 & $0.027^{*}$ \\
\hline Clay & 0.1121 & $0.012^{*}$ \\
\hline Silt & 0.0094 & 0.694 \\
\hline
\end{tabular}

${ }^{1}$ SOM-soil organic matter. R-squared—squared correlation coefficient. Significance codes: ${ }^{*} p$-value $<0.05$, ** $p$-value $<0.01, * * *$-value $<0.001$.

\section{Discussion}

The study has shown that macroinvertebrate taxa responded differently to the paddy rice farming pathways in Mpologoma catchment during the 2018-2019 period. In particular, the most ubiquitous oligochaetes were encountered in $100 \%$ of the samples from the natural wetland but the frequency reduced in the large-scale commercial and smallholder rice paddies. Similar studies have observed higher or lower frequencies of some oligochaete species in the natural grassland and/or hardwood forest than in the cultivated areas [55]. In the current study, however, oligochaetes were not identified to the lower levels; hence, differences that could arise at species levels were not captured. Nevertheless, a similar trend would be obtained with some oligochaete species showing higher or lower frequencies in the natural wetland compared with the cultivated paddies. In the rice paddies, oligochaete density also varied: it was significantly higher in the smallholder than large-scale commercial paddies. Variation in oligochaete frequency and density among sites could be attributed to the differences in soil conditions. Generally, the magnitude of physical soil disturbance through tillage and chemical disturbance through agrochemical use increases with farming intensity from the pristine natural wetland condition where the soil is largely at rest to the cultivated condition where the soil is regularly worked for farming. Such disturbance has been reported to affect the distribution of soil invertebrates within the soil column and across habitats [21,32,35]. At the large-scale commercial farm, pesticides and inorganic fertilizers are heavily used coupled with high mechanization and associated soil compaction. Conversely, the smallholder paddy rice farmers in this area do not use inorganic fertilizers; they rely on the natural fertility of the alluvial soil deposited by moving water. Soil compaction is also minimal. Therefore, these factors could have made the soil environment at the large-scale commercial farm less conducive to oligochaetes compared with that in the smallholder rice paddies and natural wetland [32,34,56-58]. In addition, the lowest oligochaete density observed in the commercial fallow stage was attributed to the farm management dynamics whereby plots that were not in active agricultural use were not supplied with irrigation water. Consequently, this could have increased the concentration of agrochemical residues in those plots which jeopardized oligochaete survival [59].

Gastropod density also varied among sites, being highest in the large-scale commercial rice paddies and lowest in the natural wetland. Gastropods are largely herbivorous organisms and some are avid feeders on young rice stems [60-62]. Therefore, the stable food supply at the large-scale farm where rice is grown throughout the year coupled with reduced predation from diplopods and chilopods [63] could have been major drivers for the high density of gastropods in the large-scale rice paddies. Additionally, the scaring away of birds by the bird chasers who are employed by the commercial farm could also 
have significantly contributed to the reduced predation on snails by the predatory birds, such as the African Jacana (Actophilornis africanus) and ducks, among others [41].

Densities for individual arthropod taxa were low except coleoptera and did not significantly vary among sites. Nevertheless, some arthropods showed habitat exclusiveness. In this category were the detritivorous diplopods which were exclusive to the natural wetland. Their exclusivity could be attributed to litter availability because the short fallow periods (usually one season or none) in the cultivated large-scale and smallholder rice paddies coupled with the routine soil disturbance may not have allowed sufficient time for litter to accumulate in these fields compared with the natural wetland where the soil had negligible perturbations. Similarly, Diplurans were only found in the large-scale commercial rice paddies, as previously documented [64]. This preference could be related to high prey abundances, such as insect larvae (e.g., Coleopteran nymphs and Trichopteran larvae), in the large-scale paddies compared with the natural wetland and smallholder rice paddies. Furthermore, some studies have documented high Acari and Collembola abundance in vineyards $[20,65]$ relative to other arthropods, but in our study these taxa had low densities and insignificantly contributed to the dissimilarity among sites. This implies that it is difficult to make generalizations about macroinvertebrate abundances and diversity in varying agricultural systems because the agricultural practices vary and are complex, yet the response of macroinvertebrates might be a habitat-specific occurrence [66].

Land use conversion from natural wetland to cultivated rice fields, especially conversion to the large-scale commercial paddy rice farming, was also associated with increased richness and diversity of macroinvertebrates. Indeed, the rank-abundance relationship confirmed a higher macroinvertebrate evenness in the large-scale rice paddies than other sites. This contrasts with similar studies where diversity of macroinvertebrates decreased with increasing land use intensification [55,67]. The high diversity at the large-scale commercial farm could be attributed to the near-mosaic farm setup, where the bunds of natural vegetation that separate plots, strips, and blocks, and the road network which provides access to the plots, could have created refugia that enhanced macroinvertebrate diversity [68].

From the ordination system, macroinvertebrate communities of smallholder paddies and natural wetland seemed to be highly similar. This was attributed to the high proximity of the smallholder paddies to the natural wetland which could have easily allowed fauna mobility between the two adjacent sites in the landscape [20,69]. Furthermore, the NMDS regression showed that soil $\mathrm{pH}$, calcium, phosphorus, clay, and sand were the major paddy soil variables that had significant relationships with the ordination pattern. Similar studies [65] have reported factors such as soil $\mathrm{pH}, \mathrm{SOM}$, and temperature to be important soil environment variables that drive invertebrate distribution, especially arthropods, in vineyards. They found texture to be insignificant; however, we found that texture, especially clay and sand content, were significantly correlated with macroinvertebrate distribution in rice paddies. This implies that the soil environment of rice paddies could be influenced by some unique factors unlike terrestrial croplands, and these would need further exploration. Nevertheless, this study has highlighted that changes in soil properties could play a role in driving the community characteristics of macroinvertebrates in rice paddies.

This study recorded some macroinvertebrate taxa that are not regular soil residents. These included Hirudinea, Decapoda, Ephemeroptera, Trichoptera, and Odonata. Of these, Hirudinea have previously been observed in some studies [70]. What could be driving such taxa to wetlands and paddies in particular is not certain, but could be attributed to the wetland environment itself, as some taxa have to return to water to breed, making flooded wetlands suitable habitats. Additionally, the changing climate could be impacting the breeding behavior of these taxa in ways that are not currently known. Our study used an unbalanced design where some samples especially from the natural wetland were less than those from other sites. We think that this could have somehow affected these results, though some authors (e.g., Milliken and Johnson [71]) argue that lack of balance does not usually affect results in a single-factor ANOVA. 


\section{Conclusions}

This study aimed to evaluate the response of soil macroinvertebrates to paddy rice farming pathways during the 2018-2019 period. A total of 18 macroinvertebrate taxa were observed, dominated by Oligochaeta. Three taxa: Oligochaeta, Gastropoda, and Coleoptera accounted for most of the dissimilarity among sites. Some taxa showed habitat exclusivity: Decapoda, Chilipoda, Diplopoda, and Blattodea were exclusive to the natural wetland, while two taxa (Diplura and Ephemeroptera) were exclusive to the large-scale commercial paddies. No taxa were exclusive to smallholder paddies and none to both smallholder and natural wetland. However, three taxa (Diptera, Odonata, and Trichoptera) were common to both large-scale commercial and smallholder paddies. Considering richness and diversity, large-scale commercial paddies generally had higher richness and diversity than natural wetland and smallholder paddies. Among the soil environmental variables, $\mathrm{pH}$, phosphorus, calcium, clay, and sand seemed to most influence the macroinvertebrate community in the study area. We also observed some taxa that are not usually in soils. These included Hirudinea, Decapoda, Ephemeroptera, Trichoptera, and Odonata. Further studies are needed to extend experiments to other paddy rice farming contexts, monitor macroinvertebrate diversity over a longer term in a balanced design, and explore the potential of using such taxa in monitoring soil quality in rice paddies. The studies would identify indicator macroinvertebrate species that are tolerant or intolerant to chemical and physical soil disturbance in the paddies. It would also be necessary to identify any other apparently new macroinvertebrate taxa in paddies that could be using wetlands during some of their growth stages to respond to the changing global climate. Rice farmers, especially the smallholders, should also mosaic their paddy rice fields with natural areas to create refugia, increasing macroinvertebrate biodiversity.

Supplementary Materials: The following are available online at: https:/ /www.mdpi.com/article/ 10.3390/agronomy12020312/s1, Table S1: Percentage composition of soil macroinvertebrate taxa by site and crop stage, Table S2: Proportion of soil samples where macroinvertebrate taxa were encountered per site and crop stage, Table S3: Soil characteristics (Mean $\pm \mathrm{SE}$ ) per site and crop stage.

Author Contributions: Conceptualization, J.B., A.W.M., N.N.G. and A.E.; methodology, J.B., A.W.M. and N.N.G.; validation, J.B., A.W.M. and N.N.G.; formal analysis, J.B.; investigation, J.B. and A.W.M.; data curation, J.B., A.W.M., N.N.G., M.J.G.M. and A.E.; writing-original draft preparation, J.B., A.W.M., N.N.G., M.J.G.M. and A.E.; writing-review and editing, J.B., A.W.M., N.N.G., M.J.G.M. and A.E.; visualization, J.B. and A.W.M.; supervision, A.W.M., N.N.G. and M.J.G.M.; project administration, J.B.; funding acquisition, J.B. and A.E. All authors have read and agreed to the published version of the manuscript.

Funding: This research was funded by RUFORUM under the Social and Environmental Tradeoffs in African Agriculture (SENTINEL) Project of the Global Challenges Research Fund (GCRF), Research Councils UK (Grant \# RU/2018/GTA/DRG/039), and Makerere University (DELP Small Research Grant).

Institutional Review Board Statement: Not applicable. This study did not involve animal or human subjects.

Informed Consent Statement: Not applicable. This study did not involve human subjects.

Data Availability Statement: The data presented in this study are openly available in FigShare at https:/ / doi.org/10.6084/m9.figshare.17040803.v1 (accessed on 9 November 2021).

Acknowledgments: We thank the farm owners who allowed us to carry out research in their fields. We are very grateful to our field assistants Benjamin Simiyu and David from Kibimba farm for assisting with language interpretation and other field-related activities that smoothened our fieldwork in the farmers' paddies. We appreciate Aguttu Gorret from Makerere University for chemical analysis of soil samples and the technical staff of the School of Biological Sciences, University of Nairobi, for lab and materials during macroinvertebrate sample collection and lab analysis.

Conflicts of Interest: The authors declare no conflict of interest. 


\section{References}

1. FAO. Sustainable Agriculture: A Tool to Strengthen Food Security and Nutrition in Latin America and the Caribbean: 2014-2015 Highlights; FAO: Rome, Italy, 2016.

2. $\quad$ Stringer, L.C.; Fraser, E.D.G.; Harris, D.; Lyon, C.; Pereira, L.; Ward, C.F.M.; Simelton, E. Adaptation and Development Pathways for Different Types of Farmers. Environ. Sci. Policy 2020, 104, 174-189. [CrossRef]

3. Van Nguyen, N.; Ferrero, A. Meeting the Challenges of Global Rice Production. Paddy Water Environ. 2006, 4, 1-9. [CrossRef]

4. Norman, J.C.; Kebe, B. African Smallholder Farmers: Rice Production and Sustainable Livelihoods. International Rice Commission Newsletter; FAO: Rome, Italy, 2006.

5. Chenoune, R.; Belhouchette, H.; Paloma, S.G.Y.; Capillon, A. Assessing the Diversity of Smallholder Rice Farms Production Strategies in Sierra Leone. NJAS-Wagening J. Life Sci. 2016, 76, 7-19. [CrossRef]

6. Rodenburg, J.; Zwart, S.J.; Kiepe, P.; Narteh, L.T.; Dogbe, W.; Wopereis, M.C.S. Sustainable Rice Production in African Inland Valleys: Seizing Regional Potentials through Local Approaches. Agric. Syst. 2014, 123, 1-11. [CrossRef]

7. Tomich, T.P.; Lidder, P.; Coley, M.; Gollin, D.; Meinzen-Dick, R.; Webb, P.; Carberry, P. Food and Agricultural Innovation Pathways for Prosperity. Agric. Syst. 2019, 172, 1-15. [CrossRef]

8. OECD-FAO. Agricultural Outlook 2018-2027; OECD Publishing: Paris, France; FAO: Rome, Italy, 2018.

9. Annual Report 2018-International Rice Research Institute (IRRI) by Glenn Concepcion-Issuu. Available online: https: / / issuu. com/glennconcepcion/docs/irri_annual_report_2018 (accessed on 9 November 2021).

10. Pingali, P.L.; Rosegrant, M.W.; Prabhu, L.; Mark, W. Confronting the Environmental Consequences of the Green Revolution In Asia. Educ. New Environ. Leadersh. Asia 1994, 2, 61-74.

11. Roger, P.A.; Heong, K.L.; Teng, P.S. Biodiversity and Sustainability of Wetland Rice Production: Role and Potential of Microorganisms and Invertebrates. In The Biodiversity of Microorganisms and Invertebrates: Its Role in Sustainable Agriculture; CAB International: Wallingford, UK, 1991

12. Keesstra, S.D.; Bouma, J.; Wallinga, J.; Tittonell, P.; Smith, P.; Cerdà, A.; Montanarella, L.; Quinton, J.N.; Pachepsky, Y.; Van Der Putten, W.H.; et al. The Significance of Soils and Soil Science towards Realization of the United Nations Sustainable Development Goals. Soil 2016, 2, 111-128. [CrossRef]

13. Lavelle, P.; Bignell, D.; Lepage, M.; Wolters, V.; Roger, P.; Ineson, P.; Heal, O.W.; Dhillion, S. Soil Function in a Changing World: The Role of Invertebrate Ecosystem Engineers. Eur. J. Soil Biol. 1997, 33, 159-193.

14. Lavelle, P.; Decaëns, T.; Aubert, M.; Barot, S.; Blouin, M.; Bureau, F.; Margerie, P.; Mora, P.; Rossi, J.P. Soil Invertebrates and Ecosystem Services. Eur. J. Soil Biol. 2006, 42, S3-S15. [CrossRef]

15. Schmidt, A.; John, K.; Arida, G.; Auge, H.; Brandl, R.; Horgan, F.G.; Hotes, S.; Marquez, L.; Radermacher, N.; Settele, J.; et al Effects of Residue Management on Decomposition in Irrigated Rice Fields Are Not Related to Changes in the Decomposer Community. PLoS ONE 2015, 10, e0134402. [CrossRef] [PubMed]

16. Brussaard, L.; de Ruiter, P.C.; Brown, G.G. Soil Biodiversity for Agricultural Sustainability. Agric. Ecosyst. Environ. 2007, 121, 233-244. [CrossRef]

17. Frouz, J. Effects of Soil Macro- and Mesofauna on Litter Decomposition and Soil Organic Matter Stabilization. Geoderma 2018, 332, 161-172. [CrossRef]

18. Gardi, C.; Montanarella, L.; Arrouays, D.; Bispo, A.; Lemanceau, P.; Jolivet, C.; Mulder, C.; Ranjard, L.; Römbke, J.; Rutgers, M.; et al. Soil Biodiversity Monitoring in Europe: Ongoing Activities and Challenges. Eur. J. Soil Sci. 2009, 60, 807-819. [CrossRef]

19. Schmidt, A.; Auge, H.; Brandl, R.; Heong, K.L.; Hotes, S.; Settele, J.; Villareal, S.; Schädler, M. Small-Scale Variability in the Contribution of Invertebrates to Litter Decomposition in Tropical Rice Fields. Basic Appl. Ecol. 2015, 16, 674-680. [CrossRef]

20. Menta, C.; Conti, F.D.; Fondón, C.L.; Staffilani, F.; Remelli, S. Soil Arthropod Responses in Agroecosystem: Implications of Different Management and Cropping Systems. Agronomy 2020, 10, 982. [CrossRef]

21. Barbercheck, M.E.; Neher, D.A.; Anas, O.; El-Allaf, S.M.; Weicht, T.R. Response of Soil Invertebrates to Disturbance across Three Resource Regions in North Carolina. Environ. Monit. Assess. 2009, 152, 283-298. [CrossRef]

22. Kibblewhite, M.G.; Ritz, K.; Swift, M.J. Soil Health in Agricultural Systems. Philos. Trans. R. Soc. B Biol. Sci. 2008, 363, 685-701. [CrossRef]

23. Herrick, J.E. Soil Quality: An Indicator of Sustainable Land Management? Appl. Soil Ecol. 2000, 15, 75-83. [CrossRef]

24. Gedoz, M.; Freitas, E.M.; da Silva, V.L.; Johann, L. Edaphic Invertebrates as Indicators of Soil Integrity Quality. Floresta E Ambiente 2021, 28, e20200069. [CrossRef]

25. Parisi, V.; Menta, C.; Gardi, C.; Jacomini, C.; Mozzanica, E. Microarthropod Communities as a Tool to Assess Soil Quality and Biodiversity: A New Approach in Italy. Agric. Ecosyst. Environ. 2005, 105, 323-333. [CrossRef]

26. Neave, P.; Fox, C.A. Response of Soil Invertebrates to Reduced Tillage Systems Established on a Clay Loam Soil. Appl. Soil Ecol. 1998, 9, 423-428. [CrossRef]

27. Errouissi, F.; Moussa-Machraoui, S.B.; Ben-Hammouda, M.; Nouira, S. Soil Invertebrates in Durum Wheat (Triticum Durum L.) Cropping System under Mediterranean Semi-Arid Conditions: A Comparison between Conventional and No-Tillage Management. Soil Tillage Res. 2011, 112, 122-132. [CrossRef]

28. Cates, A.M.; Ruark, M.D.; Hedtcke, J.L.; Posner, J.L. Long-Term Tillage, Rotation and Perennialization Effects on Particulate and Aggregate Soil Organic Matter. Soil Tillage Res. 2016, 155, 371-380. [CrossRef] 
29. Jones, D.T.; Susilo, F.X.; Bignell, D.E.; Hardiwinoto, S.; Gillison, A.N.; Eggleton, P. Termite Assemblage Collapse along a Land-Use Intensification Gradient in Lowland Central Sumatra, Indonesia. J. Appl. Ecol. 2003, 40, 380-391. [CrossRef]

30. Sharley, D.J.; Hoffmann, A.A.; Thomson, L.J. The Effects of Soil Tillage on Beneficial Invertebrates within the Vineyard. Agric. For. Entomol. 2008, 10, 233-243. [CrossRef]

31. Karlen, D.L.; Wollenhaupt, N.C.; Erbach, D.C.; Berry, E.C.; Swan, J.B.; Eash, N.S.; Jordahl, J.L. Long-Term Tillage Effects on Soil Quality. Soil Tillage Res. 1994, 32, 313-327. [CrossRef]

32. Bluett, C.; Tullberg, J.N.; McPhee, J.E.; Antille, D.L. Soil and Tillage Research: Why Still Focus on Soil Compaction? Soil Tillage Res. 2019, 194, 104282. [CrossRef]

33. John, K.; Zaitsev, A.S.; Wolters, V. Soil Fauna Groups Respond Differentially to Changes in Crop Rotation Cycles in Rice Production Systems. Pedobiologia 2021, 84, 150703. [CrossRef]

34. Förster, B.; Garcia, M.; Francimari, O.; Römbke, J. Effects of Carbendazim and Lambda-Cyhalothrin on Soil Invertebrates and Leaf Litter Decomposition in Semi-Field and Field Tests under Tropical Conditions (Amazônia, Brazil). Eur. J. Soil Biol. 2006, 42, S171-S179. [CrossRef]

35. Cole, L.; Buckland, S.M.; Bardgett, R.D. Influence of Disturbance and Nitrogen Addition on Plant and Soil Animal Diversity in Grassland. Soil Biol. Biochem. 2008, 40, 505-514. [CrossRef]

36. Saifutdinov, R.A.; Sabirov, R.M.; Zaitsev, A.S. Springtail (Hexapoda: Collembola) Functional Group Composition Varies between Different Biotopes in Russian Rice Growing Systems. Eur. J. Soil Biol. 2020, 99, 103208. [CrossRef]

37. Government of Uganda. Uganda National Rice Development Strategy (N RDS): 2008-2018; Ministry of Agriculture, Animal Industry and Fisheries: Kampala, Uganda, 2012.

38. Kolawole, O. Smallholder Farming Practices: Synthesis, Critical Reflections and Policy Issues; Nova Science: New York, NY, USA, 2019; pp. 249-260.

39. Index. Available online: https://ipad.fas.usda.gov/highlights/2015/06/Southeast_Asia/Index.htm (accessed on 9 November 2021).

40. Murphy, S. Changing Perspectives: Small-Scale Farmers, Markets and Globalization; IIED: London, UK; Hivos: The Hague, The Netherlands, 2010.

41. BirdLife Data Zone. Available online: http://datazone.birdlife.org/index.php/site/factsheet/kibimba-rice-scheme-iba-uganda (accessed on 9 November 2021).

42. Bunyangha, J.; Majaliwa, M.J.G.; Muthumbi, A.W.; Gichuki, N.N.; Egeru, A. Past and Future Land Use/Land Cover Changes from Multi-Temporal Landsat Imagery in Mpologoma Catchment, Eastern Uganda. Egypt. J. Remote Sens. Space Sci. 2021, 24, 675-685. [CrossRef]

43. Swift, M.; Bignell, D. Standard Methods for Assessment of Soil Biodiversity and Land Use Practice; ICRAF: Bogor, Indonesia, $2001 ;$ p. 40.

44. Baillie, I.C.; Anderson, J.M.; Ingram, J.S.I. Tropical Soil Biology and Fertility: A Handbook of Methods. J. Ecol. 1990, $78,547$. [CrossRef]

45. Okalebo, J.R. Laboratory Methods of Soil and Plant Analysis: A Working Manual, 2nd ed.; SACRED Africa: Nairobi, Kenya, 2002; pp. 1-131.

46. United States Department of Agriculture. USDA Textural Soil Classification. In Soil Mechanics Level I Module 3-USDA Textural Soil Classification; United States Department of Agricultur: Washington, DC, USA, 1987; pp. 1-53.

47. Maurer, B.A.; McGill, B.J. Measurement of Species Diversity. Biol. Divers. Front. Meas. Assess 2011, 345, 55-65.

48. Help, C.H.R.; Herman, P.M.J.; Soetaert, K. Indices of Diversity and Evenness. Oceanis 1998, 24, 61-87.

49. Kim, B.R.; Shin, J.; Guevarra, R.B.; Lee, J.H.; Kim, D.W.; Seol, K.H.; Lee, J.H.; Kim, H.B.; Isaacson, R.E. Deciphering Diversity Indices for a Better Understanding of Microbial Communities. J. Microbiol. Biotechnol. 2017, 27, 2089-2093. [CrossRef]

50. Brower, J.E.; Zar, J.H.; Von Ende, C.N. Field and Laboratory Methods for General Ecology; McGraw-Hill Education: New York, NY, USA, 1997; p. 288.

51. R: The R Project for Statistical Computing. Available online: https://www.r-project.org/ (accessed on 9 March 2021).

52. Kenkel, N.C.; Orloci, L. Applying Metric and Nonmetric Multidimensional Scaling to Ecological Studies: Some New Results. Ecology 1986, 67, 919-928. [CrossRef]

53. Clarke, K.R. Non-Parametric Multivariate Analyses of Changes in Community Structure. Aust. J. Ecol. 1993, 18, 117-143. [CrossRef]

54. Oksanen, J.; Blanchet, F.G.; Friendly, M.; Kindt, R.; Legendre, P.; McGlinn, D.; Minchin, P.R.; O’Hara, R.B.; Simpson, G.L.; Solymos, P.; et al. Vegan: Community Ecology Package. 2020. Available online: https://cran.r-project.org/web/packages/ vegan/vegan.pdf (accessed on 9 March 2021).

55. Callaham, M.A.; Richter, D.D.; Coleman, D.C.; Hofmockel, M. Long-Term Land-Use Effects on Soil Invertebrate Communities in Southern Piedmont Soils, USA. Eur. J. Soil Biol. 2006, 42 (Suppl. 1), 150-156. [CrossRef]

56. França, F.M.; De Paiva, T.C.B.; Marcantônio, A.S.; Teixeira, P.C.; Ferreira, C.M. Acute Toxicity and Ecotoxicological Risk Assessment of Rice Pesticides to Lithobates Catesbeianus Tadpoles. J. Environ. Sci. Health-Part B Pestic. Food Contam. Agric. Wastes 2015, 50, 406-410. [CrossRef]

57. Gimeno-García, E.; Andreu, V.; Boluda, R. Heavy Metals Incidence in the Application of Inorganic Fertilizers and Pesticides to Rice Farming Soils. Environ. Pollut. 1996, 92, 19-25. [CrossRef]

58. Gunstone, T.; Cornelisse, T.; Klein, K.; Dubey, A.; Donley, N. Pesticides and Soil Invertebrates: A Hazard Assessment. Front. Environ. Sci. 2021, 9, 122. [CrossRef] 
59. Calderbank, A. The Occurrence and Significance of Bound Pesticide Residues in Soil. Rev. Environ. Contam. Toxicol. 1989, 108, 71-103. [CrossRef]

60. Fang, L.; Wong, P.K.; Lin, L.; Lan, C.; Qiu, J.W. Impact of Invasive Apple Snails in Hong Kong on Wetland Macrophytes, Nutrients, Phytoplankton and Filamentous Algae. Freshw. Biol. 2010, 55, 1191-1204. [CrossRef]

61. Sheldon, S.P. The Effects of Herbivorous Snails on Submerged Macrophyte Communities in Minnesota. Ecology 2013, 68, 1920-1931. [CrossRef]

62. Yusa, Y.; Sugiura, N.; Wada, T. Predatory Potential of Freshwater Animals on an Invasive Agricultural Pest, the Apple Snail Pomacea Canaliculata (Gastropoda: Ampullariidae), in Southern Japan. Biol. Invasions. 2006, 8, 137-147. [CrossRef]

63. Barker, G.M. Millipedes (Diplopoda) and Centipedes (Chilopoda Myriapoda) as Predators of Terrestrial Gastropods. Nat. Enemies Terr. Molluscs 2004, 405-426.

64. Widyastuti, R. Feeding Rate of Soil Animals in Different Ecosystems in Pati, Indonesia. Hayati J. Biosci. 2006, 13, 119-123. [CrossRef]

65. Ghiglieno, I.; Simonetto, A.; Orlando, F.; Donna, P.; Tonni, M.; Valenti, L.; Gilioli, G. Response of the Arthropod Community to Soil Characteristics and Management in the Franciacorta Viticultural Area (Lombardy, Italy). Agronomy 2020, 10, 740. [CrossRef]

66. Bedano, J.C.; Domínguez, A.; Arolfo, R.; Wall, L.G. Effect of Good Agricultural Practices under No-till on Litter and Soil Invertebrates in Areas with Different Soil Types. Soil Tillage Res. 2016, 158, 100-109. [CrossRef]

67. Barros, E.; Pashanasi, B.; Constantino, R.; Lavelle, P. Effects of Land-Use System on the Soil Macrofauna in Western Brazilian Amazonia. Biol. Fertil. Soils 2002, 35, 338-347. [CrossRef]

68. Keppel, G.; Van Niel, K.P.; Wardell-Johnson, G.W.; Yates, C.J.; Byrne, M.; Mucina, L.; Schut, A.G.T.; Hopper, S.D.; Franklin, S.E. Refugia: Identifying and Understanding Safe Havens for Biodiversity under Climate Change. Glob. Ecol. Biogeogr. 2012, 21, 393-404. [CrossRef]

69. Tuck, S.L.; Winqvist, C.; Mota, F.; Ahnström, J.; Turnbull, L.A.; Bengtsson, J. Land-Use Intensity and the Effects of Organic Farming on Biodiversity: A Hierarchical Meta-Analysis. J. Appl. Ecol. 2014, 51, 746-755. [CrossRef] [PubMed]

70. Li, W.; Dou, Z.; Cui, L.; Zhao, X.; Zhang, M.; Zhang, Y.; Gao, C.; Yang, Z.; Lei, Y.; Pan, X. Soil Fauna Diversity at Different Stages of Reed Restoration in a Lakeshore Wetland at Lake Taihu, China. Ecosyst. Health Sustain. 2020, 6, 1722034. [CrossRef]

71. Milliken, G.A.; Johnson, D.E. Analysis of Messy Data. Volume 1: Designed Experiments, 1st ed.; Van Nostrand Reinhold: New York, NY, USA, 1984; p. 127. 